\title{
SOMATIC HYPERMUTATION INTRODUCES A HIGH FREQUENCY OF AMINO ACID SUBSTITUTIONS IN THE CONSTANT REGION OF THE T CELL RECEPTOR ALPHA CHAIN IN BALLAN WRASSE (LABRUS BERGYLTA)
}

\author{
Ivar Hordvik ${ }^{\S}$, Sumaira Bilal \\ Department of biology, High Technology Centre, University of Bergen, Norway
}

\begin{abstract}
It was previously thought that $\mathrm{T}$ cell receptor genes were not subject to somatic hypermutation, which is in contrast to immunoglobulin genes where this mechanism is associated with a key role in the affinity maturation of the antibody response. However, recent studies in shark and camels have shown that variable $\mathrm{T}$ cell receptor gamma chain genes are hypermutated. In this presentation we show that somatic mutations on the constant part of the $\mathrm{T}$ cell receptor alpha chain gene are frequent in a teleost fish; Ballan wrasse (Labrus bergylta). We examined many Tcra cDNAs from the same individual to determine if constant region diversity exceeded the amount that could be attributed to germline polymorphism. It is plausible to assume that somatic hypermutation is involved in the generation of the $\mathrm{T}$ cell repertoire and that consequently mutations are introduced in the constant region gene. The amino acid substitutions we found in Ballan wrasse are primarily positioned in the loops between the beta sheets, i.e. regions that apparently are not critical for the overall structure. It has been reported that polymorphism at the constant $\mathrm{T}$ cell receptor alpha chain genes is widespread in teleosts. After we had found several amino acid substitutions in translated cDNAs present in public databases the present study was initiated in an attempt to reveal corresponding polymorphism in Atlantic salmon (Salmo salar). Although we sequenced the gene in several individuals from rivers in Norway, Russia and Canada we only found some germline mutations in untranslated regions.
\end{abstract}

\section{KEYWORDS}

Teleost, T cell receptor, somatic, hypermutation, polymorphism

${ }^{\S}$ Corresponding author. Tel.: +47 55584538.

E-mail address: ivar.hordvik@uib.no 